\title{
Serological Study of Nocardiae and Mycobacteria by Using "Mycobacterium" pellegrino and Nocardia corallina Precipitation Reference Systems
}

\author{
MALIN RIDELL \\ Institute of Medical Microbiology, University of Göteborg, Göteborg, Sweden
}

\begin{abstract}
The serological relationship between 125 strains of Nocardia and Mycobacterium was analyzed by means of the comparative immunodiffusion technique. Two reference precipitation systems, $N$. corallina and “ $M$." pellegrino, were utilized. Most of the tested strains had one to three precipitinogens in common with the $N$. corallina and the "M." pellegrino reference strains. Most of the mycobacterial and most of the nocardia strains examined seemed to be serologically related to the two reference strains to an equally large extent. Eight strains, either designated $N$. corallina, N. rubra, or " $M$." rhodochrous, revealed a close serological relationship with the $N$. corallina reference strain, and so it might be justified to consider these strains as belonging to one taxonomic group. Ten other strains, designated $N$. rubra, "M." pellegrino, or "M." rhodochrous, displayed a close serological relationship with the " $M$." pellegrino reference strain, and they may therefore be regarded as belonging to another taxonomic group. Eight strains with the designations $N$. corallina, $N$. rubra, or " $M$.", rhodochrous showed little serological similarity to either of the two reference strains. Thus, the present taxonomy of a number of strains of Nocardia and Mycobacterium seems questionable since some strains were found to be serologically different, although referred to the same species, whereas some strains, referred to different species, were serologically closely related. The classification and nomenclature of such strains should, therefore, be reconsidered.
\end{abstract}

The borderline between the two genera Nocardia and Mycobacterium is unclear, and the delineations between different species within these two genera are also incomplete. It is not settled, for example, whether the species tentatively designated "Mycobacterium" rhodochrous (Overbeck) Gordon and Mihm (12) should belong to Nocardia, Mycobacterium, or to some other genus $(2,8,9,11,30)$. Strains designated "Mycobacterium" pellegrino Kor̆inek have also a position which is not clear ( 2 , 14), and furthermore this name is not validly published (4). (Since it is unclear to which genus these species belong, the genus name is placed in quotation marks.)

It has been shown that strains from various species of the genera Nocardia and Mycobacterium have antigens in common. Serological analyses of the relationship between these two genera and of species within the genus Nocardia have been made by several authors, e.g., Castelnuovo et al. $(5,6)$, Magnusson $(20,21)$, and others $(15,16,26,33)$. In a recent investigation by Ridell and Norlin (27), the precipitinogenic relationships between some species of the genera mentioned above were studied. Nocardia strains and strains designated "M." pellegrino or " $M$." rhodochrous were analyzed by means of the comparative immunodiffusion technique using serological reference systems representing nine mycobacterial species. It was demonstrated that the tested strains and the mycobacterial reference strains crossreacted, having up to three precipitinogens in common.

The aim of the present study was to obtain further knowledge of the antigenic relationships of strains from the genera Nocardia and Mycobacterium, with special regard to those species having unclear taxonomic positions. For this purpose two new reference systems were prepared, namely for the species Nocardia corallina (Bergey et al.) Waksman and Henrici (32) and " $M$." pellegrino.

\section{MATERIALS AND METHODS}

Bacterial strains. The number of strains tested was 125,72 of which represented 16 different mycobacterial species (see Table 2). The number of strains 
referred to the genus Nocardia was 42 (species are indicated in Table 4). In addition, seven strains designated " $M$." pellegrino and four strains designated " $M$." rhodochrous were studied. The sources and designations of these strains and of strains labeled $N$. corallina and Nocardia rubra (Kruse) Chalmers and Christopherson (7) are indicated in Table 1.

Antigen preparations. Antigens were prepared in two different ways as described previously (27). The two types of preparations are very similar as to precipitinogenic composition (23), and so they were employed interchangeably.

Antisera. Reference immune sera for $N$. corallina (strain N. 32) and " $M$." pellegrino (strain N. 13) were prepared as follows. Rabbits were immunized by subcutaneous injections of a mixture containing 10 parts of antigen preparation (concentrated culture filtrate), 9 parts of liquid paraffin, and 1 part of Arlacel A. The rabbits received $1 \mathrm{ml}$ of this preparation once a week for 7 weeks and were bled 2 weeks after the last injection. Test bleedings during the immunization were made to evaluate the progress of the antibody response.

Serological technique. The analyses were carried out by means of a microplate modification (31) of the comparative immunodiffusion technique according to Ouchterlony $(24,25)$.

Reference precipitation systems. Reference precipi- tation systems for the species $N$. corralina and " $M$." pellegrino were prepared with strain N. 32 and strain N. 13 , respectively.

\section{RESULTS}

Reference precipitation systems for the species $N$. corallina and " $M$." pellegrino were prepared. The precipitation pattern for $N$. corallina (strain N. 32) consisted of seven separate immunoprecipitates, labeled $\mathrm{aA}^{\mathrm{co}}$. gG $^{\text {co }}$ (left pattern, Fig. 1); the pattern for " $M$." pellegrino (strain N. 13) consisted of seven separate precipitates, labeled $\mathrm{aA}^{\mathrm{pe}} \mathrm{gG}^{\mathrm{pe}}$ (left pattern, Fig. 2). The two reference strains showed two common precipitinogens. When the " $M$." pellegrino strain was analyzed by means of the $N$. corallina system, no reaction of identity could be revealed (see Table 5). In the $N$. corallina strain, however, the precipitinogen $\mathrm{a}^{\text {pe }}$ was demonstrated (see Table 7).

The number of precipitinogens revealed by the analyses of the 72 mycobacterial strains by means of the $N$. corallina system is indicated in Table 2. Antigen preparations from 15 of the

TABLE 1. Designations and sources of 28 of the strains studied

\begin{tabular}{|c|c|c|c|c|}
\hline $\begin{array}{c}\text { Laboratory } \\
\text { no. }\end{array}$ & \multicolumn{3}{|c|}{ Strain designation as received } & $\begin{array}{l}\text { Received } \\
\text { from }^{a}\end{array}$ \\
\hline N. 28 & \multicolumn{3}{|c|}{ Nocardia corallina $13004 / 148$} & 2 \\
\hline N. 29 & \multicolumn{3}{|c|}{ N. corallina $\quad 13006 / 147$} & 2 \\
\hline N. 30 & \multicolumn{3}{|c|}{ N. corallina 2287} & 2 \\
\hline N. 31 & \multicolumn{3}{|c|}{ N. corallina 2293} & 2 \\
\hline N. $32^{b}$ & \multicolumn{3}{|c|}{ N. corallina $\quad$ M-ö 5007} & 2 \\
\hline N. 52 & \multicolumn{3}{|c|}{$N$. corallina $\quad 5301$} & 1 \\
\hline N. 53 & \multicolumn{3}{|c|}{ N. corallina $\quad 5302$} & 1 \\
\hline N. 19 & \multicolumn{3}{|c|}{ Nocardia rubra 2295} & 2 \\
\hline N. 20 & \multicolumn{3}{|c|}{ N. rubra 2298} & 2 \\
\hline N. 21 & \multicolumn{3}{|c|}{ N. rubra 2299} & 2 \\
\hline N. 23 & \multicolumn{3}{|c|}{ N. rubra 2302} & 2 \\
\hline N. 24 & \multicolumn{3}{|c|}{ N. rubra 2303} & 2 \\
\hline N. 25 & \multicolumn{3}{|c|}{ N. rubra 2304} & 2 \\
\hline N. 26 & \multicolumn{3}{|c|}{ N. rubra 2305} & 2 \\
\hline N. 27 & \multicolumn{3}{|c|}{ N. rubra 2306} & 2 \\
\hline N. 50 & \multicolumn{3}{|c|}{ N. rubra $\quad 5201$} & 1 \\
\hline N. 51 & \multicolumn{3}{|c|}{ N. rubra $\quad 5202$} & 1 \\
\hline N. 12 & \multicolumn{3}{|c|}{ “Mycobacterium" pellegrino 59} & 2 \\
\hline N. $13^{b}$ & \multicolumn{3}{|c|}{ "M." pellegrino 107} & 2 \\
\hline N. 14 & \multicolumn{2}{|c|}{ "M." pellegrino } & & 2 \\
\hline N. 15 & \multicolumn{2}{|l|}{ “M." pellegrino } & & 2 \\
\hline N. 16 & \multicolumn{2}{|l|}{ “M." pellegrino } & & 2 \\
\hline N. 48 & \multicolumn{2}{|l|}{ “M." pellegrino } & & 1 \\
\hline N. 49 & \multirow{2}{*}{\multicolumn{2}{|c|}{$\begin{array}{l}\text { “M." pellegrino } \\
\text { "Mycobacterium" rhodochrous }\end{array}$}} & & 1 \\
\hline N. 35 & & & 8139 & 2 \\
\hline N. 36 & \multicolumn{2}{|c|}{ "M." rhodochrous } & 8154 & 2 \\
\hline N. 45 & \multicolumn{2}{|c|}{ "M." rhodochrous } & C 576 & 3 \\
\hline N. 46 & \multicolumn{2}{|l|}{ “M." rhodochrous } & EB 327 & 1 \\
\hline
\end{tabular}

a (1) R. Bönicke, Forschungsinstitut Borstel, Borstel, West Germany; (2) J. Juhlin, Malmö Allmänna Sjukhus, Malmö, Sweden; (3) National Collection of Type Cultures, London, England.

${ }^{b}$ Reference strain. 


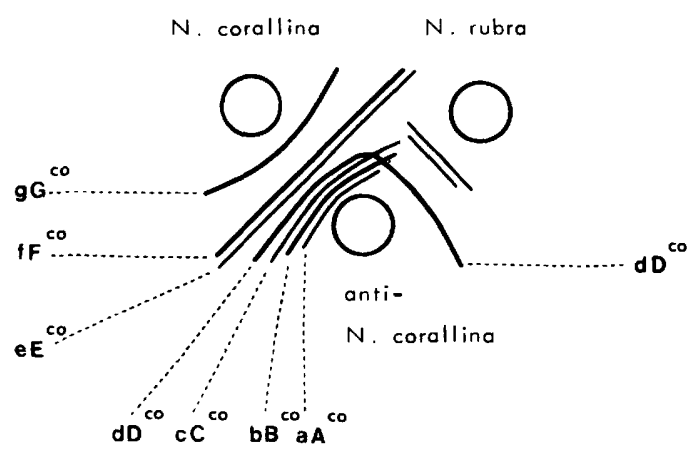

FIG. 1. Schematic illustration of immunodiffusion analysis of $N$. rubra strain (N.20) by means of the $N$. corallina reference system.

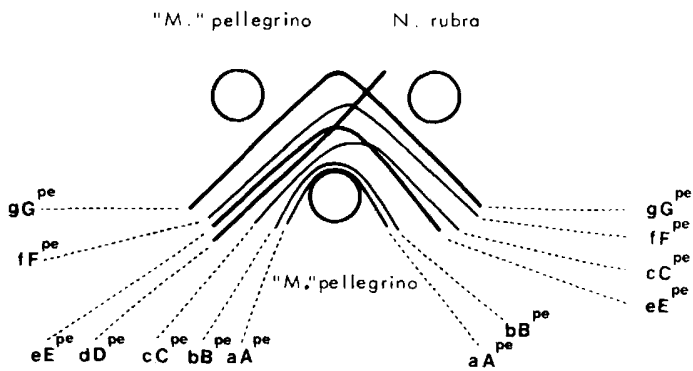

FIG. 2. Schematic illustration of immunodiffusion analysis of $N$. rubra strain (N. 20) by means of the " $M$." pellegrino reference system.

tested strains did not react with the reference antiserum, whereas antigen preparations from the other 57 strains tested formed one, two, or three precipitinogens with the antiserum. Table 3 shows the result of the same mycobacterial strains being analyzed by means of the " $M$." pellegrino reference system. Antigen preparations from nine strains did not react with the anti-“ $M$." pellegrino serum, whereas one, two, or three precipitinogens were revealed in antigen preparations from the other 63 strains tested.

Table 4 shows the result obtained when 41 Nocardia strains and the 11 "mycobacterial" strains were analyzed by means of the $N$. corallina reference system. Antigen preparations from all of the strains reacted with the reference antiserum. Most of them formed one, two, or three precipitates, and an $N$. polychromogenes strain and a strain labeled $\mathrm{No}$ cardia sp. formed four precipitates. Eight strains differed from the others by forming six or seven precipitates with the anti- $N$. corallina serum. Among these eight strains were four out of six $N$. corallina strains, two out of ten $N$. rubra strains, and two out of four " $M$." rhodochrous strains. The precipitinogens of all strains labeled $N$. corallina, $N$. rubra, " $M$." pellegrino, or “ $M$." rhodochrous which were found identical with precipitinogens of the $N$. corallina reference strain are indicated in Table 5. Not all of the precipitinogens demonstrated

TABLE 2. Distribution of mycobacterial strains of various species according to the number of precipitates demonstrated by means of the $N$. corallina reference system

\begin{tabular}{|c|c|c|c|c|c|c|}
\hline \multirow{2}{*}{$\begin{array}{l}\text { Run- } \\
\text { yon } \\
\text { group }\end{array}$} & \multirow[b]{2}{*}{ Species } & \multicolumn{4}{|c|}{$\begin{array}{l}\text { Distribution } \\
\text { of strains }\end{array}$} & \multirow{2}{*}{$\begin{array}{l}\text { Total } \\
\text { no. of } \\
\text { strains } \\
\text { tested }\end{array}$} \\
\hline & & $0^{a}$ & 1 & 2 & 3 & \\
\hline \multirow[t]{2}{*}{ I } & M. kansasii & & 3 & 5 & & 8 \\
\hline & M. marinum & 3 & 1 & 2 & 3 & 9 \\
\hline II & $\begin{array}{l}\text { M. gordonae } \\
\text { M. scrophulaceum }\end{array}$ & & $\begin{array}{l}1 \\
1\end{array}$ & 1 & 1 & $\begin{array}{l}2 \\
2\end{array}$ \\
\hline \multirow[t]{5}{*}{ III } & M. avium & 5 & 1 & 2 & 1 & 9 \\
\hline & M. gastri & 1 & 4 & 5 & & 10 \\
\hline & M. intracellulare & 1 & & 2 & & 3 \\
\hline & M. terrae & 1 & 2 & & & 3 \\
\hline & $\begin{array}{l}\text { M. xenopi } \\
\text { M. borstelense }\end{array}$ & & $\begin{array}{l}2 \\
3\end{array}$ & & & $\begin{array}{l}2 \\
3\end{array}$ \\
\hline \multirow{6}{*}{ IV } & M. fortuitum & 2 & 1 & 3 & & 6 \\
\hline & M. phlei & & 1 & 2 & 1 & 4 \\
\hline & M. smegmatis & 1 & 2 & 1 & 1 & 5 \\
\hline & M. vaccae & 1 & 3 & & & 4 \\
\hline & M. microti & & & 1 & & 1 \\
\hline & M. bovis var. BCG & & 1 & & & 1 \\
\hline
\end{tabular}

${ }^{a}$ Number of precipitates.

TABLE 3. Distribution of mycobacterial strains of various species according to the number of precipitates demonstrated by means of the " $M$." pellegrino reference system

\begin{tabular}{|c|c|c|c|c|c|c|}
\hline \multirow{2}{*}{$\begin{array}{l}\text { Run- } \\
\text { yon } \\
\text { group }\end{array}$} & \multirow[b]{2}{*}{ Species } & \multicolumn{4}{|c|}{$\begin{array}{l}\text { Distribution } \\
\text { of strains }\end{array}$} & \multirow{2}{*}{$\begin{array}{l}\text { Total } \\
\text { no. of } \\
\text { strains } \\
\text { tested }\end{array}$} \\
\hline & & $0^{a}$ & 1 & 2 & 3 & \\
\hline \multirow[t]{2}{*}{ I } & M. kansasii & 1 & 3 & 4 & & 8 \\
\hline & M. marinum & & 5 & 2 & 2 & 9 \\
\hline \multirow[t]{2}{*}{ II } & M. gordonae & & 2 & & & 2 \\
\hline & M. scrophulaceum & 1 & & 1 & & 2 \\
\hline \multirow[t]{5}{*}{ III } & M. avium & & 9 & & & 9 \\
\hline & M. gastri & & 1 & 7 & 2 & 10 \\
\hline & M. intracellulare & 1 & 2 & & & 3 \\
\hline & M. terrae & & 3 & & & 3 \\
\hline & M. xenopi & & & 2 & & 2 \\
\hline \multirow[t]{7}{*}{ IV } & M. borstelense & & 2 & 1 & & 3 \\
\hline & M. fortuitum & 3 & 2 & 1 & & 6 \\
\hline & M. phlei & & 2 & 2 & & 4 \\
\hline & M. smegmatis & 2 & 3 & & & 5 \\
\hline & M. vaccae & & 1 & 2 & 1 & 4 \\
\hline & M. microti & 1 & & & & 1 \\
\hline & M. bovis var. BCG & & 1 & & & 1 \\
\hline
\end{tabular}

${ }^{a}$ Number of precipitates. 
TABLE 4. Distribution of Nocardia strains of various species and of strains designated "M." pellegrino and "M." rhodochrous according to the number of precipitates demonstrated by means of the $N$. corallina reference system

\begin{tabular}{|c|c|c|c|c|c|c|c|c|c|}
\hline \multirow[b]{2}{*}{ Species } & \multicolumn{8}{|c|}{ Distribution of strains } & \multirow{2}{*}{$\begin{array}{l}\text { Total no. of } \\
\text { strains tested }\end{array}$} \\
\hline & $0^{a}$ & 1 & 2 & 3 & 4 & 5 & 6 & 7 & \\
\hline 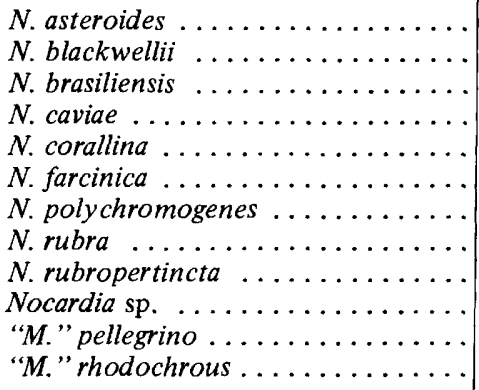 & & $\begin{array}{l}7 \\
1 \\
2 \\
2 \\
1\end{array}$ & $\begin{array}{l}5 \\
1\end{array}$ & $\begin{array}{l}2 \\
1 \\
1 \\
3 \\
1 \\
\\
4 \\
1\end{array}$ & 1 & & 2 & 2 & $\begin{array}{r}11 \\
1 \\
2 \\
3 \\
6 \\
3 \\
2 \\
10 \\
2 \\
1 \\
7 \\
4\end{array}$ \\
\hline
\end{tabular}

${ }^{a}$ Number of precipitates.

TABLE 5. Precipitinogens of strains designated N. corallina, N. rubra, "M." pellegrino, or "M." rhodochrous identified by the $N$. corallina reference system

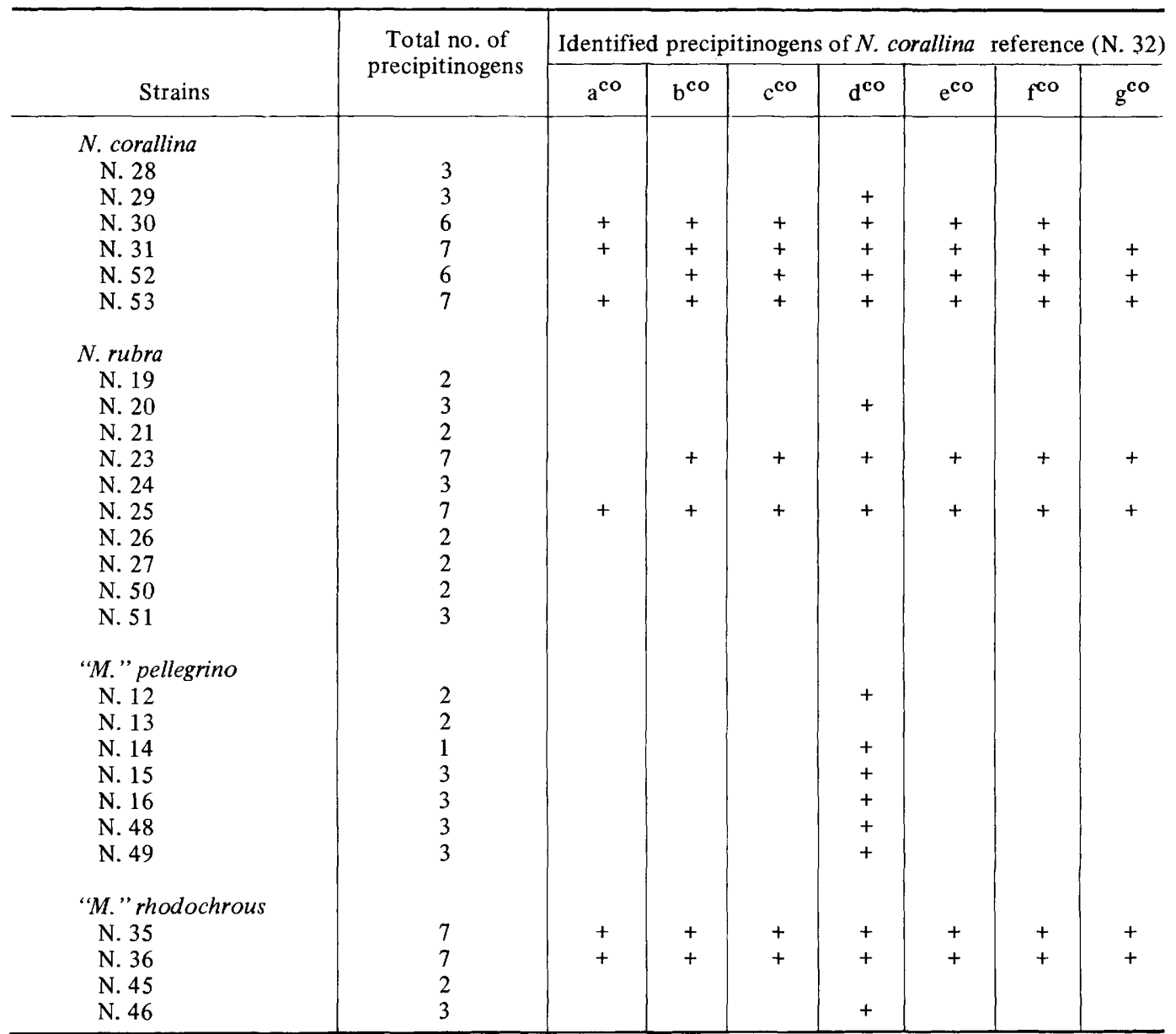


in the tested strains were identified by means of the reference pattern. All seven precipitinogens of the reference strain were identified in five strains (N. 31, N. 53, N. 25, N. 35, and N. 36), six of them were identified in three strains $(\mathrm{N}$. 30 , N. 52, and N. 23), and only one was identified in nine strains. In 10 strains none of the precipitinogens of the reference strains was demonstrated. The precipitinogen $d^{\text {co }}$ was the one most frequently demonstrated among the strains tested.

Figure 1, showing the result of a comparative immunodiffusion analysis by means of the $N$. corallina reference system, demonstrates three precipitinogens in the $N$. rubra strain N. 20 . One of the precipitinogens demonstrated was identified as $\mathrm{d}^{\mathrm{co}}$

The results obtained when antigen preparations from 42 Nocardia and 10 "mycobacterial" strains were analyzed by means of the " $M$." pellegrino reference system are given in Table 6. Antigen preparations from all strains except two (one $N$. asteroides and one $N$. blackwellii strain) reacted with the " $M$." pellegrino serum, forming from one up to seven precipitates. In 39 of the tested strains, one, two, or three precipitinogens were revealed. Four precipitinogens were revealed in one $N$. corallina strain, and five precipitinogens were revealed in one $N$. rubra and in one " $M$." pellegrino strain. Six or seven precipitinogens were revealed in eight strains. Among these eight strains were two of ten $N$. rubra strains, five of six " $M$." pellegrino strains, and one of four " $M$." rhodochrous strains. Table 7 demonstrates the identified precipitinogens in all tested strains that are referred to the species $N$. corallina, N. rubra, "M." pellegrino, and ' $M$." rhodochrous. Not all precipitinogens demonstrated in the tested strains were identified by means of the reference pattern. In three strains (N. 24, N. 12, and N. 16), however, all seven precipitinogens of the reference strain could be identified, and in six strains (N. 20, N. 14, N. 15 , N. 48, N. 49 , and N. 45), five or six of them could be identified. In most of the remaining strains, one, two, or three precipitinogens were identified. The precipitinogens $a^{\text {pe }}$ and $\mathrm{g}^{\text {pe }}$ were the factors most frequently demonstrated in the analyzed strains.

Figure 2, showing the result of a comparative immunodiffusion analysis by means of the “M." pellegrino reference system, demonstrates six precipitinogens in the $N$. rubra strain N. 20 (the same strain as in Fig. 1). All six precipitinogens in the $N$. rubra strain were identified by means of the reference pattern.

\section{DISCUSSION}

The results of this study are based on comparative immunodiffusion analyses with reference systems. This method offers a possibility to identify individual precipitates. However, precipitates obtained by the test strain and the reference antiserum $\mid$ can be unfavorably situated in relation to corresponding precipitates in the reference system, and no identity reaction can thus be revealed (compare Fig. 1). There are further reasons for failure to demonstrate identity reactions. However, the presence of a precipitate can be regarded as a demonstration of a precipitinogen common to the test strain and the reference strain.

Standardization of antigen preparations is

TABLE 6. Distribution of Nocardia strains of various species and of strains designated "M." pellegrino and " $M$." rhodochrous according to the number of precipitates revealed by means of the "M." pellegrino reference system

\begin{tabular}{|c|c|c|c|c|c|c|c|c|c|}
\hline \multirow[b]{2}{*}{ Species } & \multicolumn{8}{|c|}{ Distribution of strains } & \multirow{2}{*}{$\begin{array}{l}\text { Total no. of } \\
\text { strains tested }\end{array}$} \\
\hline & $0^{a}$ & 1 & 2 & 3 & 4 & 5 & 6 & 7 & \\
\hline$N$. asteroides $\ldots \ldots \ldots \ldots \ldots \ldots$ & 1 & 9 & & 1 & & & & & 11 \\
\hline$N$, blackwellii $\ldots \ldots \ldots \ldots \ldots \ldots \ldots$ & 1 & & & & & & & & 1 \\
\hline N. brasiliensis $\ldots \ldots \ldots \ldots \ldots \ldots$ & & 2 & & & & & & & 2 \\
\hline$N$. caviae $\ldots \ldots \ldots \ldots \ldots \ldots \ldots$ & & 1 & 1 & 1 & & & & & 3 \\
\hline$N$. corallina $\ldots \ldots \ldots \ldots \ldots \ldots$ & & 2 & 2 & 2 & 1 & & & & 7 \\
\hline$N$. farcinica $\ldots \ldots \ldots \ldots \ldots \ldots$ & & 2 & 1 & & & & & & 3 \\
\hline$N$. polychromogenes $\ldots \ldots \ldots \ldots \ldots$ & & & 2 & & & & & & 2 \\
\hline N. rubra $\ldots \ldots \ldots \ldots \ldots \ldots \ldots$ & & 1 & 1 & 5 & & 1 & 1 & 1 & 10 \\
\hline N. rubropertincta $\ldots \ldots \ldots \ldots \ldots$ & & & & 2 & & & & & 2 \\
\hline Nocardia $\mathrm{sp}, \ldots \ldots \ldots \ldots \ldots \ldots$ & & & 1 & & & & & & 1 \\
\hline "M."pellegrino $\ldots \ldots \ldots \ldots \ldots \ldots$ & & & & & & 1 & 3 & 2 & 6 \\
\hline "M." rhodochrous . . . . . . . . . . & & 1 & 1 & 1 & & & 1 & & 4 \\
\hline
\end{tabular}

\footnotetext{
${ }^{a}$ Number of precipitates.
} 
TABLE 7. Precipitinogens of strains designated N. corallina, N. rubra, "M." pellegrino, or "M." rhodochrous identified by the " $M$." pellegrino reference system

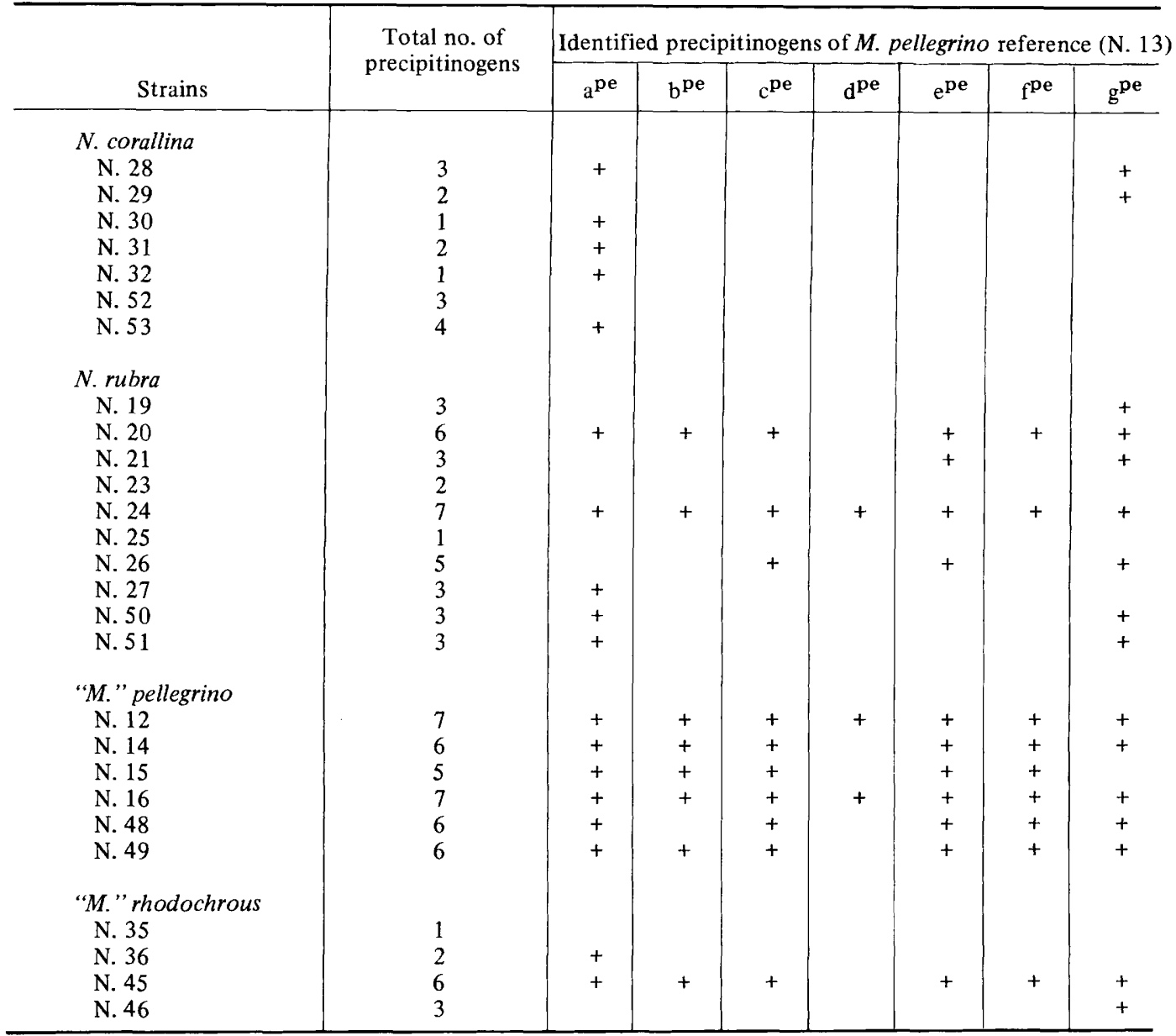

difficult, and small variations in cultivation conditions may partially explain the variations in the number of demonstrated precipitinogens. Therefore, differences of one or two precipitinogens have a limited value for differentiation purposes.

In a previous study (27), it was demonstrated that there are at least three precipitinogens common to many species of the genera Mycobacterium and Nocardia and that two of them correspond to the mycobacterial crossreacting factors $\alpha$ and $\beta$. The results of the present study showed that most of the mycobacterial strains cross-reacted with the anti- $N$. corallina and the anti-“ $M$." pellegrino reference sera, forming one, two, or three precipitates (see Tables 2 and 3), and thus confirmed the earlier results. The different mycobacterial species seemed to be serologically related to the two reference strains to a similar degree, and the " $M$." pellegrino strain was not more closely related to any of the mycobacterial species than was the $N$. corallina strain.

All of the Nocardia strains and the strains designated " $M$." pellegrino and " $M$." rhodochrous cross-reacted with the anti- $N$. corallina reference serum, and all except two crossreacted with the anti-" $M$." pellegrino reference serum. Most test strains of the Nocardia species, as for example $N$. asteroides, did not seem to be serologically more closely related to either the $N$. corallina or the " $M$." pellegrino reference strain than were strains of the genus $M y c o b a c$ terium as they had not more than three precipitinogens in common with the reference strains (see Tables 4 and 6). It should be mentioned that the tested strains labeled $N$. farcinica in an earlier study (27) reacted like Nocardia and not like Mycobacterium strains. The precipitation patterns formed by four $N$. 
corallina strains, two $N$. rubra strains, and two "M." rhodochrous strains, when analyzed by means of the $N$. corallina reference system, indicate a high degree of serological similarity between these strains and the reference strain (see Table 5). Other strains, however, with the same species designations did not show the same high degree of serological similarity to the reference strain. The results obtained when the Nocardia and "mycobacterial" strains were analyzed by means of the " $M$." pellegrino reference system show the same pattern concerning serological relationships (see Table 7). It might be appropriate to place together in one group the strains $N$. rubra (N. 23, N. 25), $N$. corallina $(\mathrm{N} .30, \mathrm{~N} .31, \mathrm{~N} .32, \mathrm{~N} .52$, and $\mathrm{N}$. 53), and "M." rhodochrous (N. 35 and N. 36). Another group can be formed by the strains “M." pellegrino (N. 12, N. 13, N. 14, N. 15, N. 16 , N. 48, and N. 49), N. rubra (N. 20, N. 24), and " $M$." rhodochrous (N. 45). Strain N. 26 might also be placed in this group. This strain has, however, a more uncertain position as indicated by the demonstration of five precipitinogens, of which three were identified when analyzed with the " $M$." pellegrino reference system. Eight of the tested strains referred to the species $N$. corallina, $N$. rubra, or " $M$." rhodochrous were not closely related to any of the two reference strains (having at most three precipitinogens in common). Thus, it seems that these eight strains should be referred to taxonomic groups other than those represented by the two reference strains.

It is of interest to note that the $N$. corallina strains N. 30, N. 31, N. 32, N. 52, and N. 53, all of which have been placed in the same serological group, display the same amidase pattern-they decompose urea and allantoinwhereas the serologically different strains N. 28 and N. 29, also designated $N$. corallina upon receipt, decompose only urea (unpublished results). Hence, strains designated $N$. corallina form at least two different taxonomic groups.

It should be mentioned that the two strains $N$. corallina $(\mathrm{N}, 32)$ and " $M$." pellegrino $(\mathrm{N}$. 13), which were chosen as the reference strains, are not the type strains of these species and that no type strains seem to exist for these species. (28).

The 10 strains which were found to be serologically closely related to the " $M$." pellegrino reference strain also showed the same amidase pattern as the reference strain, i.e., they decompose acetamide, nicotinamide, and pyrazinamide (unpublished results). Juhasz and Bönicke (14) reported the same pattern when analyzing seven " $M$." pellegrino strains. Thus, all the " $M$." pellegrino strains formed a distinct cluster and might therefore be referred to a single species. It is also very probable that the strains $N$. rubra (N. 20, N. 24, and N. 26) and " $M$." rhodochrous (N. 45) belong to this species. The tested strains designated $N$. rubra could be divided into at least three distinct clusters-strains closely related to each of the two reference strains and strains which could not be grouped in the present study. The same heterogeneity was found among strains labeled "M." rhodochrous.

The results of the present study imply either that the present taxonomy of the genus Nocardia is unsuitable for the above-mentioned species or that the strains included in this study were incorrectly labeled when received. Castelnuovo et al. (5) have demonstrated a close serological relationship between some strains of $N$. rubra, "M." pellegrino, and " $M$." rhodochrous, and Lind et al. (19) and Adams et al. (1) have shown that " $M$." rhodochrous is a very heterogenous species. Bradley (3) found that the "rhodochrous complex" contained at least two species-one typified by $N$. corallina or $N$. rubra and the other by $N$. erythropolis. In a numerical taxonomy study of a great number of nocardioform strains, Goodfellow (8) placed within one cluster, which he called the $M$. rhodochrous group, strains designated $N$. corallina, $N$. rubra, or $N$. pellegrino, among others. This cluster was divided into several subgroups. $\mathrm{He}$ concluded that the present taxonomy of nocardioform bacteria is illogical.

Two serological groups, represented by the two reference strains, have been distinguished among the strains used in this study. There is no indication, however, to which genus-Nocardia, Mycobacterium or some other genus-the strains included in the two groups should be referred. Several investigators have discussed to which genus strains designated " $M$." pellegrino and " $M$." rhodochrous should belong. Bönicke et al. $(2,14,29)$ have studied these species and suggested the designation Nocardia pellegrino. Gordon (11-13) placed the " $M$." rhodochrous strains, tentatively, among the mycobacteria. Castelnuovo et al. $(5,17)$ proposed placing in one group some strains identified as belonging to $N$. corallina, $N$. rubra, " $M$." rhodochrous, or " $M$." pellegrino, referring this group of strains to the genus Nocardia. Bradley (3) found that strains of the "rhodochrous complex" were more allied to $N$. asteroides and $N$. farcinica than to $M$. tuberculosis. By studying lipid composition, Lechevalier et al. (18) suggested that all of the strains of " $M$." rhodochrous that they tested should be assigned to Nocardia. Tsukamura (30), on the other hand, has proposed that " $M$." rhodochrous-like organisms 
should be referred to a new genus, Gordona. Goodfellow et al. $(8,9)$ stated that numerical taxonomy indicates that the " $M$." rhodochrous complex forms a taxon clearly distinct from the genus Mycobacterium as well as from the genus Nocardia. It is interesting to note that their studies $(10,22)$ have shown that strains of the " $M$." rhodochrous complex contain a lipid similar to, but not identical with, a lipid characteristic of Nocardia. The present study indicates that some strains designated $N$. rubra, $N$. corallina, " $M$." pellegrino, or " $M$." rhodochrous are probably not more closely related to the true nocardiae (i.e., species like $N$. asteroides) than to the true mycobacteria.

It is obvious that the specific identification of a fairly large number of strains referred to Nocardia or Mycobacterium should be reconsidered because there are strains which are very different but which have been placed in the same species and there are also strains which have been placed in different species are but which are closely related.

\section{ACKNOWLEDGMENTS}

This investigation received financial support from the World Health Organization, the Swedish National Association against Heart and Chest Diseases, and the Ellen, Walter and Lennart Hesselman's Foundation.

\section{REPRINT REQUESTS}

Address reprint requests to: Dr. Malin Ridell, Institute of Medical Microbiology, Department of Bacteriology, Guldhedsgatan 10, S-413 46 Göteborg, Sweden.

\section{LITERATURE CITED}

1. Adams, M. M., J. N. Adams, and G. H. Brownell. 1970. The identification of Jensenia canicruria Bisset and Moore as a mating type of Nocardia erythropolis (Gray and Thornton) Waksman and Henrici. Int. J. Syst. Bacteriol. 20:133-147.

2. Bönicke, R., and S. E. Juhasz. 1965. Methods of differentiation of the genus Mycobacterium from the genus Nocardia. Bull. Int. Un. Tubercle 36:14-21.

3. Bradley, S. G. 1971. Criteria for definition of Mycobacterium, Nocardia and the rhodochrous complex. Advan. Front. Plant Sci. 28:349-362.

4. Buchanan, R. E., J. G. Holt, and E. F. Lessel (ed.). 1966. Index Bergeyana. The Williams \& Wilkins Company, Baltimore.

5. Castelnuovo, G., G. Bellezza, M. E. Duncan, and J. Asselineau. 1964. Etudes sur les mycobactéries et les nocardiae. Ann. Inst. Pasteur 107:828-844.

6. Castelnuovo, G., G. Bellezza, H. J. Giuliani, and J. Asselineau. 1968. Relations chimiques et im- munologiques chez les Actinomycétales. Ann. Inst. Pasteur 114:139-147.

7. Chalmers, A. J., and J. B. Christopherson. 1916. A Sudanese actinomycosis. Ann. Trop. Med. Parasitol. 10:223-282.

8. Goodfellow, M. 1971. Numerical taxonomy of some nocardioform bacteria. J. Gen. Microbiol. 69:33-80.

9. Goodfellow, M., A. Fleming, and M. J. Sackin. 1972. Numerical classification of "Mycobacterium" rhodochrous and Runyon's group IV my cobacteria. Int. J. Syst. Bacteriol. 22:81-98.

10. Goodfellow, M., D. E. Minnikin, P. V. Patel, and H. Mordarska. 1973. Free nocardomycolic acids in the classification of Nocardias and strains of the "rhodochrous" complex. J. Gen. Microbiol. 74:185-188.

11. Gordon, R. E. 1966. Some strains in search of a genus-Corynebacterium, Mycobacterium, Nocardia or what? J. Gen. Microbiol. 43:329-343.

12. Gordon, R. E., and J. M. Mihm. 1957. A comparative study of some strains received as nocardiae. J. Bacteriol. 73:15-27.

13. Gordon, R. E., and J. M. Mihm. 1959. A comparison of four species of myeobacteria. J. Gen. Microbiol. 21:736-748.

14. Juhasz, S. E., and R. Bönicke. 1965. Mycobacterium oder Norcardia pellegrino? Beitr. Klin. Tuberk. Spezifisch. Tuberk. Forsch. 130:155-169.

15. Kwapinski, J. B. G. 1969. Analytic serology of microorganisms, vol. 1, p. 2-122. Interscience Publisher, New York.

16. Kwapinski, J. B. G. 1970. Serological taxonomy and relationships of Actinomycetales, p. 345-369. In. H. Prauser Jena (ed.), The Actinomycetales. Gustav Fischer Verlag, New York.

17. Lanéele, M.-A., J. Asselineau, and G. Castelnuovo. 1965. Etudes sur les mycobactéries et les nocardiae. Ann. Inst. Pasteur 108:69-82.

18. Lechevalier, M. P., A. C. Horan, and H. Lechevalier. 1971. Lipid composition in the classification of nocardia and mycobacteria. J. Bacteriol. 105:313-318.

19. Lind, A., M. Norlin, Ö. Ouchterlony, and M. Wedel-Hansson. 1970. IUAT Conference, Sept. 1969. Report. Bull. Int. Un. Tubercle 44:84.

20. Magnusson, M. 1962. Specificity of sensitins. III. Further studies in guinea-pigs with sensitins of various species of Mycobacterium and Nocardia. Amer. Rev. Resp. Dis. 86:395-404.

21. Magnusson, M., and F. Mariat. 1968. Delineation of Nocardia farcinica by delayed type skin reactions on guinea-pigs. J. Gen. Microbiol. 51:151-158.

22. Mordarska, H., M. Mordarski, and M. Goodfellow. 1972. Chemotaxonomic characters and the classification of some nocardioform bacteria. J. Gen. Microbiol. 71:77-86.

23. Norlin, M., and R. Navalkar. 1966. Immunoprecipitinogenic spectra of culture filtrates of "anonymous" mycobacteria compared to those of bacillary cells. Bull. Int. Un. Tubercle 38:52-56.

24. Ouchterlony, Ö. 1958. Diffusion-in-gel methods for immunological analysis. I. Progr. Allergy 5:1-78.

25. Ochterlony, Ö. 1962. Diffusion-in-gel methods for 
immunological analysis. II. Progr. Allergy 6:30-154.

26. Pier, A. C., and R. E. Fichtner. 1971. Serological typing of Nocardia asteroides by immunodiffusion. Amer. Rev. Resp. Dis. 103:698-707.

27. Ridell, M., and M. Norlin. 1973. Serological study of Nocardia by using mycobacterial precipitation reference systems. J. Bacteriol. 113:1-7.

28. Sneath, P. H. A., and V. B. D. Skerman. 1966. A list of type and reference strains of bacteria. Int. J. Syst. Bacteriol. 16:1-133.

29. Tarnok, J., E. Röhrscheidt, and R. Bönicke. 1967. Basenzusammensetzung der Desoxyribonukleinsäure (DNS) von Mykobakterien und verwandten Mikroorganismen. Rass. Patol. App. Resp. 17:4:1-16.

30. Tsukamura, M. 1971. Proposal of a new genus, Gordona, for slightly acid-fast organisms occur- ring in sputa of patients with pulmonary disease and in soil. J. Gen. Microbiol. 68:15-26.

31. Wadsworth, C. 1962. A microplate technique employing a gel chamber compared with other micro- and macroplate techniques for immune diffusion. Int. Arch. Allergy 21:131-137.

32. Waksman, S. A., and A. T. Henrici. 1948. Family Actinomycetaceae Buchanan and Family Streptomycetaceae Waksman and Henrici p. 892-980. In R. S. Breed, E. G. D. Murray, and A. P. Hutchins (ed.), Bergey's manual of determinative bacteriology, 6th ed. The Williams \& Wilkins Co., Baltimore.

33. Zamora, A., L. F. Bojalil, and F. Bastarrachea. 1963. Immunologically active polysaccharides from Nocardia asteroides and Nocardia brasiliensis. J. Bacteriol. 85:549-555. 